\title{
THE APPLICATION OF MANAGEMENT ACCOUNTING TECHNIQUES AT STAR HOTELS IN DENPASAR CITY
}

\author{
Komang Ayu Krisnadewi \\ Udayana University (UNUD) \\ komangayukrisnadewi@unud.ac.id \\ Ni Made Adi Erawati \\ Udayana University (UNUD) \\ adierawati@unud.ac.id
}

Received: 25-03-2018

Revised: 21-09-2018

Accepted: $16-10-2018$

\begin{abstract}
This study aims to identify management accounting techniques applied in the hotel industry in Denpasar, Bali. Besides, this study also aims to find out how useful the information generated by the technique for management in the decision-making process. The survey results distributed offline and online are processed and analyzed by using descriptive techniques. The study results show that management accounting techniques have been applied in hotels within certain limits. The most common application of management accounting techniques employed by hotels is the preparation of flexible operating budgets and the financial performance assessment as a benchmark of budget conformity. Despite the less application of other management accounting techniques, the company realizes that the benefits resulting from this management accounting information are very important. The company's inability to provide information from other management accounting techniques is mostly caused by the inability of human resources in using such techniques.
\end{abstract}

Keywords: Application; Decision Making; Hotel; Management Accounting Survey

How to cite: Krisnadewi, K. A., \& Erawati, N. M. A. (2018). The Application Of Management Accounting Techniques At Star Hotels In Denpasar City. Akrual: Jurnal Akuntansi. 10 (1): 27-46 doi: http://dx.doi.org/10.26740/jaj.v10n1.p27-46

\section{INTRODUCTION}

Some practical studies have found that the degree of use of management accounting techniques varies among companies. Research results also denoted that this difference is caused by various factors Corporate strategy plays a crucial role in determining the application level of management accounting techniques (Goddard \& Simm, 2017; Hermawan, 2009). Managers play a role in controlling the management of a company. In this process, managers will always deal with various issues and end up with a decisionmaking. Management accounting aims at, among others, providing information to help managers in the decision-making. The level of necessity for an information from management accounting is highly dependent on the role of individual/manager in the organization. (Armitage, Howard M.; Webb, 2013; McLellan \& Moustafa, 2008; Schwarze, Wüllenweber, \& Hackethal, 2007; Urquidi \& Ripoll, 2013; Yigitbasioglu, 2017). When there is a change of leadership by successor (junior) in a family company, there is a tendency for the new manager to apply new management accounting techniques (Leotta, 
Rizza, \& Ruggeri, 2017). Other studies have shown that in organizations with high environmental uncertainty, the management accounting techniques tend to be largely applied compared to those with lower uncertainty (Hermawan, 2009). Other factors found in previous studies also show that culture (Keplinger, Feldbauer-Durstmüller, \& Mitter, 2012; Takeda \& Boyns, 2014), business scale (Penpichcha \& Nitirojntanad, 2016), and type of industry (Messner, 2016) determine the level of application of management accounting.

\section{LITERATURE REVIEW}

In addition to practical studies that found a variety of results related to the application level of management accounting techniques, there are also researchers who conducted literature studies of research on the application of management accounting. Duh, Xiao, \& Chow (2008) conducted a literature study of 283 management accounting articles published in 18 Chinese academic journals from 1997 to 2005. They found that those articles are dominated by normative or conceptual writing, followed by case study, survey, field-archival studies, and analytical modeling research. As much as 80 percent of the articles does not clearly show the application of management accounting theory but denotes that the role of management accounting has not been fully perceived by managers, in which a role gap exists between the academician's theory and manager's practice. Tucker \& Lowe, 2014 found a gap between academic research and practice in management accounting, particularly from the practitioner side. Utilization of academic research findings by practitioners is difficult due to difficulties in understanding academic research papers and limited access to research findings. The point is that academic research findings are not or less properly communicated to practitioners (Tucker \& Schaltegger, 2016; Tucker \& Lawson, 2016) and the topics of academic research are less relevant for practitioners (Tucker \& Schaltegger, 2016).

Based on the findings of previous research, it can be concluded that the application of management accounting techniques on various types of industries is diverse. There are many factors that influence how a management accounting technique is applied in a company, including the role of corporate management, cultural factors, company type, and company size. In addition, there is a gap between academics and practitioners regarding the application of management accounting techniques. Most of the previous studies have examined manufacturing industries in established areas (except Siriwiwattanakul \& Nitirojntanad, 2016; Urquidi \& Ripoll, 2013 examines the hospitality industry). To the best of the author's knowledge, no research has been conducted in the context of service industries which are not located in big cities). It hasn't been revealed yet whether management accounting techniques are applied in businesses at the local level. 
Studies in the hospitality industry need to be done considering decision-making process by the management is in any case highly require management accounting techniques, especially in facing the level of competition and the disclosure era. Data from the Central Bureau of Statistics (BPS) of Bali Province shows that the number of star hotels in Bali had increased by nearly 42 percent in 2011-2015. With the increasing number of online sales agents, the hospitality industry had been forced to compete particularly in terms of price. The increasingly disclosed information on room rates forced the hotel management to make the right decisions to be able, at least, to survive in the industry. One of the objectives of the information presented by management accounting techniques is price decision.

This research explores the application of management accounting techniques in the hospitality industry, especially star hotels, located in Denpasar City, Bali Province. The main economic driver in Bali is tourism in which the hotel industry is one of its supports. Although Denpasar is the capital of Bali province, the tourism industry is not the main economic driver in this city, unlike Badung district. The level of competition of the hotel industry in Denpasar city is not as high as in Badung district. Based on data from Central Bureau of Statistics (BPS) of Bali Province in 2017, the number of star hotels in Denpasar city in 2015 was 36 out of 281 hotels (about 12.81 percent). Although the competition is not as dramatic as that of Badung district, as the centre of governmental activities, the competition among hotels is not only about providing room for stay but also other services such as a venue for a meeting, wedding and other events. Exacerbated by the competition against the existing rental studio which seems to be unregulated or insufficiently regulated by the government.

Denpasar City as the centre of government and education should be a kind of reference for other regions regarding the application of a field of science, including management accounting. However, on the educational side, the level of the students' desire to write the final assignment in this field is considered very low. It is still unknown whether this low interest is due to a limited understanding and mastery over this field (considering the curriculum only offers 2 courses related to this field, unlike financial accounting that offers at least 5 courses) or because of its low level of application in the industrial sphere. Logically, if there are only a few courses are offered in this field, then the mastery of this field would be lower. Consequently, the level of interest to write final assignments in this field is low, leading to the rare application of the techniques taught in this field. This motivates us to conduct studies related to the extent of the application of management accounting techniques in the hospitality industry. The results of this study will be the basis for conducting further research, namely identifying factors that lead to the application of certain management accounting techniques. Therefore, the research 
question is whether certain management accounting techniques have been applied, especially in star hotels in Denpasar City, Bali Province. Furthermore, does the company feel the benefits generated by the techniques, and try to get initial information about the gap between theory and practice.

This study uses primary data in the form of questionnaires adapted from previous studies with modifications in such a way, making it easier for respondents to answer. Respondents are hotel management/accounting staff since accounting department is the division that performs management accounting related tasks. The data collected were processed by using descriptive statistics to determine the average, minimum and maximum value of each question asked. Questionnaires are disseminated directly, either online or offline to the participating hotels.

The research findings indicate that management accounting techniques have been applied in hotels within certain limits. The most common management accounting technique employed by the company is the operational budgeting which is flexibly done over an annual period. A commonly used performance evaluation is the financial performance evaluation with target benchmarks set within the budget. Other management accounting techniques (such as non-financial performance assessment, cost segregation, and strategic analysis) are slightly applied, but the company realizes the benefits of information resulted from these 30 management accounting techniques are very important. The inability of a company to provide information from other management accounting techniques is mostly due to the inability of its human resources in using such techniques. Lack of mastery of information technology also contributes the difficulty of using management accounting techniques. These findings indirectly indicate the inadequate mastery of materials related to management accounting techniques at the higher education level. As mentioned earlier, the courses on management accounting techniques are so limited that the mastery of this material is also limited and ultimately bring impact on its application in the real world.

This study is a pioneering research for subsequent research that seeks to explore the factors influencing the application of certain management accounting techniques. The findings of this study have the potential to provide an overview of the needs of management accounting techniques in the hospitality industry. Also, it can provide policymakers with the basis related to the accounting curriculum in order to fix the syllabus of management accounting courses including dissemination or training on how to apply management accounting techniques in accordance with actual practice conditions.

\section{RESEARCH METHODS}

All respondents are sampled in this study. Based on data from the Revenue Agency of Denpasar, there have been 48 star hotels in 
Denpasar by 31 December 2016. Among which are 5 five-star hotels, 11 four-star hotels, 11 three-star hotels, 14 two-star hotels and 7 one-star hotels. The number of questionnaires returned by the hotels is 34 , while the other four did not respond until the defined deadline. The data collected represents 70.8 percent response rate.

This research employed a survey technique using structured questionnaires distributed to respondents and giving respondents an opportunity to answer the reasons behind the application of management accounting techniques. The respondents of this research were the chief accountant in charge in the company. Demographic data of respondents will also be asked on the questionnaire, including the educational background, as well as their involvement in accounting related training. Respondents were requested to answer questions grouped into five categories on the application of management accounting techniques in their workplace. Questions examine two things, namely 1) how often certain management accounting techniques are used by the company (using the 5-point Likert scale, ranging from never to very frequently); and 2) how important and useful is the management accounting technique in helping the company operate more efficiently (using the 5-point Likert scale, ranging from unimportant to very important). In the event of a management accounting technique is not applied, the reasons for not applying the technique will also be explored through open questions.
This research focuses on the application of management accounting technique in the hotel industry in Denpasar City. This study covers only star hotels, considering that they are likely to have more professional business management than other types of hotel, at least in terms of accounting. The application of management accounting techniques is highly dependent on the management of financial transaction records in the company. Variables of this research are management accounting or technique used by the company. Management accounting techniques referred to in this research are those modified from research conducted by Mclellan \& Moustafa (2011) and Al-Nimer (2009) which consists of budgeting, performance evaluation, cost determination and control, decision making, and strategic analysis tools.

\section{ANALYSIS AND DISCUSSION}

\section{Hotel Data}

This study successfully collected 34 questionnaires with the hotel names listed in the appendices. As many as 5.88 percents of the hotels being sampled are one-star and fivestar hotels; 23.53 percent are two-star hotels; 38.24 percent are three-star hotels and 26.47 percent are four-star hotels. Hotel ownership is dominated by limited liability company, which is almost 80 percent, followed by individual ownership with almost 15 percent. As regards the hotel management, 38 percent is done by the owner while the rest is managed separately by external management. Almost 95 percent of the company owner is local people, with 88 
percent of the management is run by local people and the rest is managed by foreigners.

\section{Data of Research Respondents}

All respondents in this research are accounting staffs, with different position namely accounting, cost control, and purchasing. The education background of the respondents is Senior High School by 14.29 , Diploma by 10.71 percent, Bachelor Degree by 67.86 percent, and Master Degree and accounting profession by 3.57 percent respectively. The respondents who had attended accounting training is only around 20 percent. In performing the duties, 62 percent of respondents tend to spend more time on preparing reports for the management's interest while the rest more focused on preparing the financial statements. Moreover, 67.85 percent of respondents spend 75 percent of their time working on information for the management's interest, 17.85 percent in balanced proportion between information gathering and reporting, while 14.28 percent spend more time on financial reporting (financial accounting).

\section{Budgeting}

Budget is a very crucial tool for management in following the company's direction and achieving its goals. All respondents stated that the budgeting is very important and provide benefits for management. Based on the collected data, 85 percent of respondents answered that budgeting is useful for management (Panel A Table 1).
The type of budget created by all companies is the operational budget (including the sales and costs budget). About 41.18 percent respondents stated that management also arranged budget for each department. As many as 20.59 percent stated that they also do activity-based budgeting (left side of Panel B Table 1). The definite budgeting period of the company is the annual period. In addition to the annual period, 23.53 percents respondents stated that they also prepare monthly budgets, and 8.82 percents respondents said that they create weekly budgets (right side of Panel B Table 1). The static budget is used by 27 percent of respondents, while the rest have already used the flexible budget model.

In general, all respondents realized that the budget is very useful as a reference for management in achieving the target and become the basis for daily operational activities. Budget is used as a tool for assessing management performance since a budget is set as realistic as possible and adjusted to the performance of the previous period. The budget becomes a motivation for each department under the management in achieving the company's goals. In brief, respondents are well aware of the meaning and role of the budget in assisting the management of the company.

\section{Performance Evaluation}

The company performance evaluation can be done with both financial and non-financial benchmarks and a combination of both. Around 40 percent of respondents stated that 
the company always use financial performance to assess company performance. According to 65 percent of respondents, financial performance information is very important and provides benefits to management in assessing the company/ department/individual performance (Panel A Table 2). The benchmark used by 76.67 percent of companies is the achievement of profit target. In addition to achieving profit target, in equal percentage, the company also assesses performance based on the achievement of sales target. Cost efficiency is used by 55.88 percent of companies, and ROI-based performance evaluation is only carried out by 32.35 percent of companies. Based on the above-mentioned results, it can be stated that the company does not only use a single financial benchmark. The most commonly used benchmark is the achievement of profit and sales targets.

Company performance evaluation from customers perspective has always been done by 29.41 and 14.71 percent of respondents, while the rest answered never and done at a moderate level (Panel B Table 2). The benefit of using customer perspective information to assess the company/department/individual performance is perceived by 85.29 percent of respondents. None of the respondents stated that the use of this perspective performance evaluation is not beneficial to management. Benchmarks used are the customer satisfaction level and room occupancy rate. The customer satisfaction is measured based on internal surveys conducted by the company, and external surveys conducted by the sales agent. A total of 3 respondents conduct performance evaluation that based solely on internal surveys. As many as 8 respondents assess performance based only on external surveys. A total of 11 respondents use benchmarks such as customers satisfaction surveyed internally and externally as well as room occupancy rate. Only 1 (one) respondent used room occupancy rate alone. The rest is a combination of either internal or external survey and room occupancy rate.

Performance evaluations from the employees perspective and information systems capabilities are frequently done by 32.35 and 23.53 percent of respondents, while other responses vary from never to done at a medium level. The benefits of utilizing this perspective in assessing performance are felt by 70.57 (47.06 and 23.53) percent of respondents. None of the respondents stated that the use of perspective information in performance evaluation is not beneficial to management (Panel C Table 2). The benchmarks used include employees satisfaction, employees productivity, utilization of information systems, and employee turnover rate. Companies generally use the four benchmarks, although there are some companies that only use a single benchmark i.e. employee satisfaction, utilization of information systems, employee turnover, or employee productivity.

Performance evaluation based on the perspective of the company's internal business processes is not performed by 5.88 percent. 
While 61.77 percent said that they always use this benchmark. About 76.47 percent stated this benchmark is important (Panel D Table 2). The commonly used benchmarks from company's internal business are the rate of customer complaints and the speed of service delivery process.

Performance evaluations from other perspectives were also undertaken and confirmed by almost 94 percent of respondents. The benefits of performance evaluation that based on other perspectives are confirmed by 70.59 percent of hotels (Panel E Table 2). The other perspectives referred by 81.81 percent of companies using this benchmark is the hotel ratings in the industry, while the other 18.19 percent refers to the awards received from governments and NGOs.

Regarding individual performance evaluation, the company usually associate individual performance with bonus or compensation. A total of 11.76 percent of companies never give bonuses based on financial performance, while the rest of companies award bonuses based on financial performance (Panel A Table 3). A total of 20.59 percent of companies never give bonuses based on non-financial performance, while the rest of companies' answer varies from rarely to frequently (Panel B Table 3). The bonus is awarded based on the attainment of sales or profits target/budget. While the non-financial performance bonus is given based on customer satisfaction as well as awards received from outside parties.

\section{Cost Control}

Cost control is done by, one of which, knowing the cost behaviour. Costs are classified into fixed costs and variable costs. The theory states that the method of separating costs can be done with the help of statistics (high, low and regression methods) and can also be based on management experience. As many as 91.18 percents of companies perform a separation of cost. In terms of benefits, 88.24 percent of respondents feel the importance of doing the separation of costs (Panel A Table 4). Separation of cost based on management experience is done by 64.70 percent of companies, 17.64 percent use statistical methods, 2.94 percent use a combination of both, and the rest did not answer.

In order to control costs, companies need to control the quality of products or services provided. Quality costs are the costs incurred to prevent poor quality of service or to make the quality-related efforts. Only 23.53 percent of companies always prepare a report on quality costs while 17.65 percent did not prepare this report (Panel B Table 4). However, the mechanism of quality cost presentation answered by the respondents was different from the theory expressed by management accounting textbooks. Most of the companies only display the complaints filed by customers, amount of compensation given to customers in case of quality dissatisfaction, and maintenance related costs. All quality costs are displayed in combination with other accounts in the financial statements. Thus, the company does not specifically 
prepare a report on quality costs. The benefits of information presented in a quality cost reports are only felt 35.24 percent of companies, while 8.83 percent do not feel the benefits (right side of Panel A Table 4).

\section{Decision-Making}

Before deciding room rate and room sales volume, the company performs a break-even analysis. This analysis is conducted to find out in which volume should the sale be done with the rate that has been set so that company does not suffer losses or gain profits. Nearly 20 percent of companies almost never do this analysis (Panel A Table 5), while the rest have already performed this analysis, either regularly or irregularly.

Even if the break-even analysis is not conducted, it is perceived to be beneficial for the company. No company answered that a break-even analysis is not useful, while 75.76 percent felt the benefits of this analytical technique (right side of Panel A Table 5).

In determining the selling price, the company has various basic determinations. There are at least two techniques to determine the selling price used by the company, namely based on competitor price and production costs or a combination of both. The most widely used techniques are the production cost-based pricing, followed by a combination of production cost and competitor price, and lastly based on competitor price (left side of Panel B Table 5).

The determination of the selling price is closely related to the company's loss and profit. In assessing the performance of a department, sometimes companies judge based on the profit and loss of each department (Panel C Table 5). In terms of the ability of managers in controlling profit, there are terms known as controllable and uncontrollable costs. Controllable costs mean that managers have the authority to control a cost (direct costs). Uncontrollable costs mean otherwise and are generally derived from the arbitrary allocation of companies to the department.

About 17.65 percent of companies do not prepare income statements per department. The rest of companies prepare report per department with various models, e.g. prepare departmental performance reports by deducting only controllable costs (direct costs) from the revenue; by deducting all costs charged by the company, either directly or indirectly; prepare two different types of department performance reports, i.e. based on direct costs and also preparing profit loss statement involving direct and indirect costs (right side of Panel B Table 5). About 11.76 percent mentioned a different drafting model, where the companies prepare department performance report, but since departments are established on the basis of revenue and cost centres, such report does not compare revenue and cost. Thus, the report prepared is a revenue department report and a cost department report. The report that compares revenues and costs is prepared at the company level. 


\section{Strategic Analysis Tools}

In preparing the company's strategy to face competition, management requires information, both from internal and external parties. This information includes customer satisfaction, competitor strengths and weaknesses, supplier evaluation, product profitability analysis, and customer profitability analysis. Based on Panel A Table 6, it appears that some companies never perform customer satisfaction analysis. However, there are many companies which always perform customer satisfaction analysis in determining corporate strategy. From the benefits standpoint, 96.97 percent of companies realize that this analysis has huge benefits and none of them stated this analysis is not useful.

The utilization of information related to competitor's strengths and weaknesses is needed in mapping the strategy to be taken the company. Panel B Table 6 shows a quite unbalanced comparison between the frequency of use of this analysis and the perceived benefits. Companies that always use this analytical technique is only 70.59 percent, but the benefits of this analysis are perceived by almost all companies i.e. 90.91 percent. The imbalance occurs due to the difficulty the companies face in obtaining information from competitors. The validity of information provided by competitors seems to be questioned by the company.

The company's strategy is also determined by the supplier. Talking about hospitality industry in the current era of advanced technology and communication, the 36 dominating supplier is travel agents that supply guest. Travel agents are now classified into two groups: offline sales agents and online sales agents. Perhaps, most of the agents supplying guest to hotels are online sales agents, i.e. Agoda, Booking.com, Expedia, Traveloka, and the like. In setting the strategy, 67.65 percent of companies always conduct an analysis or evaluation of the presence of this guest supplier. A total of 29.41 percent conducted a supplier analysis in moderate frequency, and 2.94 percent had never conducted this analysis. This analysis is perceived as very useful by 84.85 percent of companies (Panel C Table 6). Imbalance also occurs in this analysis where the level of use is low but the benefit enjoyed by the company is huge.

In selling the product, the company must decide which product types should be sold or prioritized. The role of product profitability analysis is very important in setting priority. When the frequency of use and the benefits of product profitability analysis were compared, the imbalance was also found. A total of 73.53 percent of companies always conduct this analysis but 87.88 percent of them actually benefit from the results of this analysis (Panel D Table 6).

In addition to assessing the most profitable products, the company can also conduct customer profitability analysis. Similar to product analysis, the imbalance between the frequency of use and the perceived benefit from customer profitability analysis also exist. Compared with product 
Krisnadewi, Erawati ,The Application Of Management Accounting...

profitability, the level of use of customer profitability analysis is much less (i.e. only 67.65 percent) while its benefit rate is 84.85 percent, also lower than that of the product profitability analysis (Panel E Table 6).

\section{Discussion}

Based on the questionnaire results from respondents related to the application of management accounting techniques, it can be seen that some management accounting techniques have been used by the companies. Among a number of techniques in question, budgeting is the most common management accounting technique used by the companies.

Budget is very instrumental in helping companies to facilitate management functions, both in planning, coordination and control. In the industrial world, the budget acts as a guide in sales, production, financial and administrative and general policies. The main objective of the budget is to allow all planning and coordination so as to obtain maximum benefits and use of financial resources for the best interests (Burke, 1951). In addition to the industrial world, the public sector also recognizes the central role of budgeting. Budgeting plays a role in assessing managerial responsibility (Anessi-pessina, Barbera, Sicilia, \& Steccolini, 2016). This is likely to cause budgeting to be the most common management accounting technique.

The type of budget that most companies make is a flexible budget related to annual operations. The benefits of budgeting are felt by the companies especially in terms of determining performance targets and performance assessment. The budget becomes a kind of work reference that plays a vital role in assessing performance. It is reinforced by respondents who stated that the company's financial performance evaluation is more dominated by the achievement of sales/cost/profit target in accordance with the budget.

As budget plays vital roles in a company, the company's performance evaluation is thus dominated by financial performance than other perspectives, followed by business process performance, other perspectives, as well as employee perceptions and information systems. The evaluation that based on the customers perspective is in the last order. The results of this study contradict the study which states that customer performance is a prominent driver of performance and should be considered as an important part of the future performance measurement and management systems (Alsoboa, 2015; Kim, Cho, \& Brymer, 2013). Especially in the hospitality industry that is closely related to direct service to customers. Probably the hotel surveyed in this study felt that its financial performance would certainly be influenced by performance from the customer's perspective. Therefore, the company is likely to feel that customer performance will automatically be reflected in financial performance. The inability of this study to explain this result is a limitation of this study. 
Provision of bonus to individuals/ departments/ companies is also more likely to be done based on financial performance evaluation. It turned out that the benefits of information generated from performance evaluation are in line with the frequency of use, which is dominated by the benefits of information from a financial perspective. However, regarding the benefits of information from a non-financial perspective, companies recognize that performance evaluation from the customers perspective is more important than any other perspective. Performance evaluation using a variety of measures, both financial and non-financial, is believed to be beneficial for the company (Sholihin, Pike, \& Mangena, 2010). This is supported by Altin, Schwartz, \& Uysal (2017) which show that the role of revenue management is vital in supporting the success of financial performance. Even so, companies have a tendency to use more financial performance measures in assessing company performance (Mia \& Patiar, 2001).

The techniques in decision-making related to on sales volume have been conducted routinely by the companies, though in a limited percentage (less than 50 percent). Imbalance occurs when assessing the benefits of break-even information, in which more than 50 percent of respondents perceive the huge benefits of information from this analysis. Related to pricing, companies frequently use methods that based on production/service costs. As regards the departmental performance evaluation, for companies that 38 make up profit centres for each department, performance evaluation for each department is done by preparing department income statement. Evaluation models mostly use the direct income statement, in which the department's earnings is reduced by direct costs controlled by the department concerned.

In respect of strategic analysis, the same imbalance occurs between the frequency of use and the perceived benefit of each of the analytical methods asked. The frequency of customer satisfaction analysis is less than the perceived benefit of information generated from the analysis. It is likewise the analysis of competitors' strengths and weaknesses, supplier (sales agents) evaluation, product profitability, and customer profitability. The results of previous literature studies show the role of customer and supplier analysis. Studies show that companies that carry out this analysis will benefit the company (MarkhamBagnera, 2016) found that online ratings on hotel performance provided by supplier attributes on the financial performance of a hotel.

Strategic analysis that is not carried out by hotels surveyed is more caused due to the difficulties a company face in applying such analysis techniques. Respondents expressed that their human resources are lacking mastery of such techniques and mastery of information and communication technology which ultimately contribute to the inability of providing this information. However, data on the respondents' educational background shows that most of them (47.05 percent) have 
an accounting and management educational background. It indicates that there is a gap between the management accounting science acquired in higher education and the existing practices in companies. This finding is in line with previous research showing a gap between the world of education and the world of practitioners (Tucker, B.P., Schaltegger, 2016; Tucker \& Lawson, 2016; Tucker \& Lowe, 2014). In contrast to the findings of research conducted by (Duh et al., 2008) which stated that the role of management accounting has not been fully perceived by managers, and there is a role gap according to academician (theory) with managers (practice). This study confirms that management feels the benefits of each management accounting technique in anaging the company, but the company has not been able to apply it due to lacking mastery of the technique by human resources it has. Real examples of the application of each method are not readily available, thus the staffs dealing with accounting reporting in the company cannot apply the technique. Askarany \& Nasseri (2016) suggested that "roles of management accountants require new forms of education and training, with more emphasis on the practicality of the subjects that are taught in higher education institutions to accounting students". Beside from the internal side, the limited application of this technique is also caused by some external information which is difficult for the company to obtain, especially information from competitors.

\section{CONCLUSION}

The study found that the management accounting techniques have been applied within certain limits. The more contemporary techniques are rarely applied due to the lack of knowledge and the limited IT skills of human resources. The implication of this study is the need for academicians to consider aligning the management accounting curriculum in universities with the type of information managers need from management accounting technique. Giving examples related to the application of a technique, the way of calculating and utilizing information from management accounting techniques should be tailored to the practice at the company. It is expected that the examples would make it easier for companies-especially the hospitality industry-to use certain management accounting techniques and ultimately become better prepared to compete in the hospitality industry.

The application of management accounting techniques in this study varies from one hotel to another. This study has a limitation where the object includes various type of star hotels in Denpasar City. Further research needs to consider the factors which are expected to encourage a company to apply a management accounting technique. Focusing only on one type of star hotel seem more appropriate given the level of business complexity amongst star hotels is varied. Fivestar hotels are generally more complex than the one-star so that the possibility of utilizing certain management accounting techniques is 
dominant. This study only conducted a survey on the application of management accounting techniques. Future research needs to explore more in the reasons for applying or not applying certain management accounting techniques.

\section{REFERENCES}

Al-Nimer, M. B. (2009). An exploratory study on factors influencing the adoption of management accounting practices in developing countries: evidence from Jordan. AAA 2011 Management Accounting Section (MAS) Meeting Paper, 1-23. https://doi.org/10.2139/ssrn.1661975

Alsoboa, S. (2015). The External Orientation of Strategic Management Accounting: Customer Accounting, Business Strategies, and Customer. Research Journal of Finance and Accounting, $6(18)$.

Altin, M., Schwartz, Z., \& Uysal, M. (2017). "Where you do it" matters: The impact of hotels' revenue-management implementation strategies on performance. International Journal of Hospitality Management, 67, 46-52. doi:10.1016/j.ijhm.2017.08.001

Anessi-pessina, E., Barbera, C., Sicilia, M., \& Steccolini, I. (2016). Public sector budgeting: A European review of accounting and public-management journals. Accounting, Auditing \& Accountability Journal, 29(3), 20. https://doi.org/10.1108/AAAJ-11-20131532

Armitage, Howard M.; Webb, A. (2013). The Use of Management Accounting Techniques by Canadian Small and Medium Sized Enterprises: A Field Study. https://doi.org/10.2139/ssrn.2201163

Askarany, D., \& Nasseri, A. (2016). Management accounting education for the 21 st century firms. International Journal of Finance and Managerial Accounting, 1(1), 75-77.
Burke, W. L. (1951). Budgeting as an Aid to Management. Budgeting and Management, (October), 254-268. https://doi.org/10.1111/j.14678500.1959.tb02358.x

Duh, R.-R., Xiao, Z. Z., \& Chow, C. W. (2008). An Overview and Assessment of Contemporary Management Accounting Research in China. Journal of Management Accounting Research, 20, 129-164. https://doi.org/10.2139/ssrn.1003995

Goddard, A., \& Simm, A. (2017). Management accounting, performance measurement and strategy in English local authorities. Public Money \& Management, 37(4), 261-268. https://doi.org/10.1080/09540962.2017.1 295726

Hermawan, S. (2009). Perilaku Informasi Akuntansi Manajemen. Jurnal Ekonomi Manajemen Dan Akuntansi (EMISI), FE UMSIDA., 2(1). Retrieved from http://ekonomi.umsida.ac.id/tinymcpuk/g ambar/file/penelitian_sigit/Perilaku_Infor masi_Akuntansi_Manajemen_U.pdf

Keplinger, K., Feldbauer-Durstmüller, B., \& Mitter, C. (2012). Management accounting practices in a multicultural environment: Evidence from Austria, Russia and the US. International Journal of Strategic Management, 12(1), 37-49. https://doi.org/10.2139/ssrn.2009635

Kim, W. G., Cho, M., \& Brymer, R. A. (2013). Determinants affecting comprehensive property-level hotel performance: The moderating role of hotel type. International Journal of Hospitality Management, 34(1), 404412. https://doi.org/10.1016/j.ijhm.2012.12.002

Leotta, A., Rizza, C., \& Ruggeri, D. (2017). Management accounting and leadership construction in family firms. Qualitative Research in Accounting \& Management, 14(2), 189-207. https://doi.org/10.1108/QRAM-09-20150079

Markham-Bagnera, S. D. . (2016). An examination of online ratings on hotel performance indicators: An analysis of the Boston hotel market. https://doi.org/10.31274/etd-180810-5598 
Mclellan, J. D., \& Moustafa, E. (2011). Management Accounting Practices in the GULF Cooperative Countries. International Journal of Business and Accounting, and Finance, 6(1), 1-15.

McLellan, J. D., \& Moustafa, E. (2008). An Exploratory Analysis of the Importance of Management Accounting Tools in the GCC Countries. Journal of Economic and Administrative Sciences, 24(2), 5477.

https://doi.org/10.1108/10264116200800008

Messner, M. (2016). Does industry matter? How industry context shapes management accounting practice. Management Accounting Research, 31, 103-111.

https://doi.org/10.1016/j.mar.2015.09.001

Mia, L., \& Patiar, A. (2001). The use of management accounting systems in hotels: an exploratory study. International Journal of Hospitality Management, 20(2), 111-128. doi:10.1016/s0278-4319(00)00033-5

Penpichcha, K. S., \& Nitirojntanad. (2016). Management Accounting Practices in Thailand. Proceedings of the Fourth European Academic Research Conference on Global Business, Economics, Finance and Banking (EAR 16 Swiss Conference. 7 - 9 July 2016, (2016), 1-16.

Schwarze, F., Wüllenweber, K., \& Hackethal, A. (2007). Drivers of and barriers to management accounting change. AAA MAS Meeting Paper, 2007, 0-46. https://doi.org/http://dx.doi.org/10.2139/s srn. 1003371

Sholihin, M., Pike, R., \& Mangena, M. (2010). Reliance on multiple performance measures and manager performance. Journal of Applied Accounting Research, 11(1), 24-42. https://doi.org/10.1108/09675421011050018

Takeda, H., \& Boyns, T. (2014). Management, accounting and philosophy: The development of management accounting at Kyocera, 1959-2013. Accounting, Auditing \& Accountability Journal, 27(2), 317-356.

https://doi.org/10.1108/AAAJ-10-2013-1495
Tucker, B.P., Schaltegger, S. (2016). Comparing the research-practice gap in management accounting: A view from professional accounting bodies in Australia and Germany. Accounting, Auditing \& Accountability Journal, 29(3). https://doi.org/10.1016/S02784254(03)00059-0

Tucker, B. P., \& Lawson, R. (2016). Moving Academic Management Accounting Research Closer to Practice: A View from US and Australian Professional Accounting Bodies. Advances in Management Accounting, 167-206. https://doi.org/10.1108/S1474787120160000027005

Tucker, B. P., \& Lowe, A. D. (2014). Practitioners are from Mars; academics are from Venus? Accounting, Auditing \& Accountability Journal, 27(3), 394-425. https://doi.org/10.1108/AAAJ-01-201200932

Urquidi, A. C., \& Ripoll, V. M. (2013). The Choice of Management Accounting Techniques in the Hotel Sector: The Role of Contextual Factors. Journal of Management Research, 5(2), 65-82. https://doi.org/10.5296/jmr.v5i2.2520

Yigitbasioglu, O. M. (2017). Drivers of management accounting adaptability: the agility lens. Journal of Accounting \& Organizational Change, 13(2), 262-281. https://doi.org/10.1108/JAOC-12-20150092. 
Appendix

Table 1. Budgeting

Panel A

Comparison of Frequency of Use and Budget Benefit

\begin{tabular}{lr}
\hline & Frequency (\%) \\
\hline 1 (Never) & 6.06 \\
\hline 2 & 6.06 \\
\hline 3 & 21.21 \\
\hline 4 & 12.12 \\
\hline 5 (Often) & 54.55 \\
\hline & 100.00 \\
\hline
\end{tabular}

\begin{tabular}{lr}
\hline \multicolumn{2}{c}{ Benefit $(\%)$} \\
\hline 1 (Useless) & - \\
\hline 2 & - \\
\hline 3 & 14.71 \\
\hline 4 & 14.71 \\
\hline 5 (Very useful) & 70.59 \\
\hline & 100.00 \\
\hline
\end{tabular}

Panel B

Budget Preparation

\begin{tabular}{lr}
\hline \multicolumn{3}{c}{ Budget Type (\%) } \\
\hline Operational & 100.00 \\
\hline Department & 41.18 \\
\hline ABC & 20.59 \\
\hline
\end{tabular}

Time Period $(\%)$

\begin{tabular}{lr}
\hline Yearly & 100.00 \\
\hline Monthly & 23.53 \\
\hline Weekly & 8.82 \\
\hline Daily & 11.76 \\
\hline
\end{tabular}

Table 2. Performance Evaluation

Panel A

Comparison of Frequency and Benefits of Financial Based Performance

\begin{tabular}{lr}
\hline \multicolumn{2}{c}{ Frequency (\%) } \\
\hline 1 (Never) & - \\
\hline 2 & 9.09 \\
\hline 3 & 21.21 \\
\hline 4 & 30.30 \\
\hline 5 (Often) & 39.39 \\
\hline & 100.00 \\
\hline
\end{tabular}

\begin{tabular}{lr}
\multicolumn{2}{c}{ Benefit $(\%)$} \\
\hline 1 (Useless) & - \\
\hline 2 & - \\
\hline 3 & 11.76 \\
\hline 4 & 23.53 \\
\hline 5 (Very useful) & 64.71 \\
\hline & 100.00 \\
\hline
\end{tabular}

Panel B

Comparison of Frequency and Benefits of Customer Based Performance

\begin{tabular}{lr}
\hline \multicolumn{3}{c}{ Frequency (\%) } \\
\hline 1 (Never) & 2.94 \\
\hline 2 & 5.88 \\
\hline 3 & 47.06 \\
\hline 4 & 14.71 \\
\hline 5 (Often) & 29.41 \\
\hline & 100.00 \\
\hline
\end{tabular}

\begin{tabular}{lr}
\multicolumn{2}{c}{ Benefit (\%) } \\
\hline 1 (Useless) & - \\
\hline 2 & 2.94 \\
\hline 3 & 11.76 \\
\hline 4 & 29.41 \\
\hline 5 (Very useful) & 55.88 \\
\hline & 100.00 \\
\hline
\end{tabular}


Krisnadewi, Erawati ,The Application Of Management Accounting...

Panel C

Comparison of Frequency and Benefits of Employee-Based Performance

\begin{tabular}{lr}
\hline \multicolumn{2}{c}{ Frequency (\%) } \\
\hline 1 (Never) & 2.94 \\
\hline 2 & 5.88 \\
\hline 3 & 35.29 \\
\hline 4 & 23.53 \\
\hline 5 (Often) & 32.35 \\
\hline & 100.00 \\
\hline
\end{tabular}

\begin{tabular}{lr}
\multicolumn{2}{c}{ Benefit (\%) } \\
\hline 1 (Useless) & - \\
\hline 2 & 2.94 \\
\hline 3 & 26.47 \\
\hline 4 & 23.53 \\
\hline 5 (Very useful) & 47.06 \\
\hline & 100.00 \\
\hline
\end{tabular}

\section{Panel D}

Comparison of Frequency and Benefits of Business Process-Based Performance

\begin{tabular}{lr}
\hline \multicolumn{2}{c}{ Frequency (\%) } \\
\hline 1 (Never) & 5.88 \\
\hline 2 & 5.88 \\
\hline 3 & 26.47 \\
\hline 4 & 23.53 \\
\hline 5 (Often) & 38.24 \\
\hline & 100.00 \\
\hline
\end{tabular}

\begin{tabular}{lr}
\multicolumn{2}{c}{ Benefit (\%) } \\
\hline 1 (Useless) & 2.94 \\
\hline 2 & - \\
\hline 3 & 20.59 \\
\hline 4 & 26.47 \\
\hline 5 (Very useful) & 50.00 \\
\hline & 100.00 \\
\hline
\end{tabular}

Table 2. Performance Evaluation

Panel E

Comparison of Frequency and Benefit of Other Performance Assessments

\begin{tabular}{|c|c|c|c|}
\hline \multicolumn{2}{|c|}{ Frequency $(\%)$} & \multicolumn{2}{|c|}{ Benefit $(\%)$} \\
\hline 1 (Never) & 5.88 & 1 (Useless) & 2.94 \\
\hline 2 & 8.82 & 2 & 5.88 \\
\hline 3 & 32.35 & 3 & 20.59 \\
\hline 4 & 17.65 & 4 & 26.47 \\
\hline \multirow[t]{2}{*}{5 (Often) } & 35.29 & 5 (Very useful) & 44.12 \\
\hline & 100.00 & & 100.00 \\
\hline
\end{tabular}

Table 3. Performance Compensation

\section{Panel A}

Financial-Based Compensation

\begin{tabular}{|c|c|c|c|}
\hline \multicolumn{2}{|c|}{ Frequency $(\%)$} & \multicolumn{2}{|c|}{ Benefit (\%) } \\
\hline 1 (Never) & 11.76 & 1 (Useless) & 2.94 \\
\hline 2 & 8.82 & 2 & 5.88 \\
\hline 3 & 32.35 & 3 & 26.47 \\
\hline 4 & 17.65 & 4 & 17.65 \\
\hline 5 (Often) & 29.41 & 5 (Very useful) & 47.06 \\
\hline & 100.00 & & 100.00 \\
\hline
\end{tabular}




\section{Panel B}

Non Financial-Based Compensation

\begin{tabular}{|c|c|c|c|}
\hline \multicolumn{2}{|c|}{ Frequency $(\%)$} & \multicolumn{2}{|c|}{ Benefit $(\%)$} \\
\hline 1 (Never) & 20.59 & 1 (Useless) & 15.15 \\
\hline 2 & 17.65 & 2 & 9.09 \\
\hline 3 & 41.18 & 3 & 33.33 \\
\hline 4 & 8.82 & 4 & 12.12 \\
\hline \multirow[t]{2}{*}{5 (Often) } & 11.76 & 5 (Very useful) & 30.30 \\
\hline & 100.00 & & 100.00 \\
\hline
\end{tabular}

Table 4. Cost Control

\section{Panel A}

Cost Separation

\begin{tabular}{|c|c|c|c|}
\hline \multicolumn{2}{|c|}{ Frequency $(\%)$} & \multicolumn{2}{|c|}{ Benefit (\%) } \\
\hline 1 (Never) & - & 1 (Useless) & - \\
\hline 2 & 8.82 & 2 & 11.76 \\
\hline 3 & 23.53 & 3 & 20.59 \\
\hline 4 & 20.59 & 4 & 17.65 \\
\hline \multirow[t]{2}{*}{5 (Often) } & 47.06 & 5 (Very useful) & 50.00 \\
\hline & 100.00 & & 100.00 \\
\hline
\end{tabular}

Panel B

Quality Cost Report

\begin{tabular}{|c|c|c|c|}
\hline \multicolumn{2}{|c|}{ Frequency $(\%)$} & \multicolumn{2}{|c|}{ Benefit (\%) } \\
\hline 1 (Never) & 17.65 & 1 (Useless) & 8.82 \\
\hline 2 & 5.88 & 2 & 2.94 \\
\hline 3 & 38.24 & 3 & 32.35 \\
\hline 4 & 14.71 & 4 & 20.59 \\
\hline \multirow[t]{2}{*}{5 (Often) } & 23.53 & 5 (Very useful) & 35.29 \\
\hline & 100.00 & & 100.00 \\
\hline
\end{tabular}

Table 5. Decision Making

\section{Panel A}

Break Even Analysis

\begin{tabular}{|c|c|c|c|}
\hline \multicolumn{2}{|c|}{ Frequency $(\%)$} & \multicolumn{2}{|c|}{ Benefit (\%) } \\
\hline 1 (Never) & 9.09 & 1 (Useless) & - \\
\hline 2 & 9.09 & 2 & 9.09 \\
\hline 3 & 33.33 & 3 & 15.15 \\
\hline 4 & 12.12 & 4 & 24.24 \\
\hline \multirow[t]{2}{*}{5 (Often) } & 36.36 & 5 (Very useful) & 51.52 \\
\hline & 100.00 & & 100.00 \\
\hline
\end{tabular}


Krisnadewi, Erawati ,The Application Of Management Accounting...

Panel B

Determination of Selling Prices

\begin{tabular}{|c|c|}
\hline \multicolumn{2}{|c|}{ Frequency $(\%)$} \\
\hline Based on competitor & 21.21 \\
\hline Based on production cost & 42.42 \\
\hline Both & 36.36 \\
\hline & 100.00 \\
\hline \multicolumn{2}{|l|}{ Panel C } \\
\hline \multicolumn{2}{|c|}{ Comparison of Frequency and Benefit of Departmer } \\
\hline \multicolumn{2}{|c|}{ Frequency $(\%)$} \\
\hline 1 (Never) & 3.03 \\
\hline 2 & 6.06 \\
\hline 3 & 15.15 \\
\hline 4 & 21.21 \\
\hline \multirow[t]{2}{*}{5 (Often) } & 54.55 \\
\hline & 100.00 \\
\hline
\end{tabular}

Department P / L Report

\begin{tabular}{lr}
\multicolumn{2}{c}{ Frequency $(\%)$} \\
\hline Hanya biaya langsung & 35.29 \\
\hline Seluruh biaya & 20.59 \\
\hline $\begin{array}{l}\text { Model biaya langsung dan juga } \\
\text { keseluruhan biaya }\end{array}$ & 14.71 \\
\hline Lainnya & 11.76 \\
\hline Tidak menyusun & 17.65 \\
\hline
\end{tabular}

Tabel 6. Strategic Analysis

Panel A

Comparison of Frequency and Benefit of Customer Satisfaction Analysis

\begin{tabular}{lr}
\hline \multicolumn{2}{c}{ Frequency $(\boldsymbol{\%})$} \\
\hline Never & 2.94 \\
\hline Sometimes & 11.76 \\
\hline Often & 85.29 \\
\hline & 100.00 \\
\hline
\end{tabular}

\begin{tabular}{cc}
\hline \multicolumn{2}{|c|}{ Bepefit (\%) } \\
\hline 1 (Useless) & 3.13 \\
\hline 2 & 3.13 \\
\hline 3 & 6.25 \\
\hline 4 & 25.00 \\
\hline 5 (Very useful) & 62.50 \\
\hline
\end{tabular}

\section{Panel B}

Comparison of Frequency and Benefit of Competitor Analysis

\begin{tabular}{|c|c|c|c|}
\hline \multicolumn{2}{|c|}{ Frequency $(\%)$} & \multicolumn{2}{|c|}{ Benefit (\%) } \\
\hline Never & 2.94 & Useless & - \\
\hline Sometimes & 26.47 & Useful & 9.09 \\
\hline \multirow[t]{2}{*}{ Often } & 70.59 & Very useful & 90.91 \\
\hline & 100.00 & & 100.00 \\
\hline
\end{tabular}

Panel C

Comparison of Frequency and Benefit of Supplier Analysis

\begin{tabular}{|c|c|c|c|}
\hline \multicolumn{2}{|c|}{ Frequency (\%) } & \multicolumn{2}{|c|}{ Benefit (\%) } \\
\hline Never & 2.94 & Useless & 3.03 \\
\hline Sometimes & 29.41 & Useful & 12.12 \\
\hline
\end{tabular}


AKRUAL: Jurnal Akuntansi, volume 10, issue 1, October 2018 (27-46)

$\begin{array}{rrrr}\text { Often } & 67.65 & \text { Very useful } & 84.85 \\ & 100.00 & & 100.00 \\ \end{array}$

Panel D

Comparison of Frequency and Benefit of Product Profitability Analysis

\begin{tabular}{lr}
\hline \multicolumn{2}{c}{ Frequency (\%) } \\
\hline Never & 2.94 \\
\hline Sometimes & 23.53 \\
\hline Often & 73.53 \\
\hline
\end{tabular}

\begin{tabular}{lr}
\multicolumn{2}{c}{ Benefit (\%) } \\
\hline Useless & - \\
\hline Useful & 12.12 \\
\hline Very useful & 87.88 \\
\hline & 100.00 \\
\hline
\end{tabular}

Panel E

Comparison of Frequency and Benefit of Customer Profitability Analysis

\begin{tabular}{|c|c|c|c|}
\hline \multicolumn{2}{|c|}{ Frequency (\%) } & \multicolumn{2}{|c|}{ Benefit (\%) } \\
\hline Never & 2.94 & Useless & - \\
\hline Sometimes & 29.41 & Useful & 15.15 \\
\hline Often & 67.65 & Very useful & 84.85 \\
\hline & 100.00 & & 100.00 \\
\hline
\end{tabular}

